\title{
Anaerobic Digestion of Dairy Manure in a Fixed Bed CSTR: Methane Production Performance and Microbial Diversity
}

Haipeng Wang, ${ }^{\text {a }}$ Yiquan Zhao, ${ }^{\text {a }}$ Anyi Yang, ${ }^{\mathrm{a}}$ Lei Yan, ${ }^{\mathrm{a}}$ Teng Teeh Lim, ${ }^{\mathrm{c}}$ Hongyan Zhao, ${ }^{\mathrm{d}}$ Ji-Dong Gu, ${ }^{\mathrm{e}}$ Dan Wei, ${ }^{\mathrm{f}, *}$ and Weidong Wang ${ }^{\mathrm{a}, \mathrm{b}, *}$

To improve the fixed bed and continuous stirred-tank reactor (CSTR) technology relative to the rate of treatment of dairy manure (DM), a continuous stirred tank-treated DM with immobilized carrier biofilm was investigated for 20 days (hydraulic retention time (HRT) was $10 \mathrm{~d}$ ). Methane productivity, biofilm characteristics, and microbial diversities of the biofilm and digestate were measured. The highest content of extracellular polymeric substances (EPS), proteins, and polysaccharides occurred at 15 days of digestion. An agglomeration phenomenon was observed using a scanning electron microscope on the biofilm. This indicated that the biofilm consisting of EPS was stable during the second HRT. Microbial diversities in digestate and carrier biofilm were characterized using a $16 \mathrm{~S}$ rRNA sequencing technique. Results showed that the dominant bacterial communities were Pseudomonas (17\% to $26 \%$ ), Clostridium (13\% to $21 \%$ ), and Bacteroidetes (7\% to $16 \%$ ), while the archaea communities were Methanocorpusculum (25\% to $37 \%$ ), Methanosarcina (15\% to $33 \%)$, Methanoculleus $(11 \%$ to $15 \%)$, and Methanosaeta (13\% to $18 \%)$. The methane production rate was significantly correlated with bacterial communities (Pseudomonas, Clostridium, Altererythrobacter atlanticus), archaeal communities (Methanosarcina, Methanoculleus, Methanosaeta, and Methanoplanus), and biofilm characteristics (chemical oxygen demand (COD) and EPS). These findings showed that a carrier biofilm could efficiently increase methane production.

Keywords: Fixed bed; Methane; Biofilm; Microbial diversity; Dairy manure; Biotechnology

Contact information: a: Heilongjiang Provincial Key Laboratory of Environmental Microbiology and Recycling of Agro-Waste in Cold Region, Heilongjiang Bayi Agricultural University, Daqing, Heilongjiang 163319 China; b: Engineering Research Center of Processing and Utilization of Grain By-products, Ministry of Education, Daqing, Heilongjiang 163319 China; c: Agriculture Systems Management, Division of Food Systems and Bioengineering, University of Missouri, Columbia, MO 65211-5200 USA; d: College of Agronomy, Yanbian University, Yanji, Jilin133002 China; e: Guangdong Technion-Israel Institute of Technology, 241 Daxue Road, Shantou, Guangdong 515000 China; f: Institute of Plant Nutrition and Resources, Beijing Academy of Agricultural and Forestry Sciences, Beijing 100000 China;

*Corresponding authors: Weidong Wang,wwdcyy@126.com; Dan Wei,wd2087@163.com

\section{INTRODUCTION}

Biomass consists of a wide range of materials, including animals, plants, microorganisms, and their excreta, such as: crops, wood waste, and animal manure (Abbasi et al. 2010). Large amounts of biomass are exposed to the natural world-potentially occupying human living spaces and contaminating the environment. A popular technology

Wang et al. (2020). "Anaerobic digestion of manure," BioResources 15(4), 7965-7979. 
for treating organic biomass is anaerobic digestion (AD). This technology has the potential to decrease the amount of discharged biomass after treatment, and it also can produce a bioenergy product, biogas, for biomass power generation. A continuously stirred tank reactor (CSTR) is one of the configurations in the $\mathrm{AD}$ process that could provide greater uniformity of system parameters, such as temperature, mixing, chemical concentration, substrate concentration, and could also produce more biogas than a plug flow reactor (PFR) could (Li et al. 2007; Usack et al. 2012).

However, much of the AD process was designed to discharge digestate and beneficial microorganisms, which leads to a loss of the microorganism culture, biogas productivity, and extended hydraulic retention time (HRT), thus lowering the overall AD efficiency. The AD materials have been used to support the establishment of biofilms to better retain microorganisms and increase biogas production (Schauer-Gimenez et al. 2010). The role of the fixed bed is to immobilize microorganisms when they flow through carriers and to form a biofilm to enhance biological activity. The biofilm becomes the integrated unit that is a main part of the AD reactors (Langerak et al. 1998) and is critical to bio-methane production. Liu et al. (2017) utilized polypropylene fiber as a carrier and corn straw as a feedstock to increase biogas and methane production by $44.8 \%$ and $49.8 \%$, respectively. Activated carbon fiber (ACF), polyvinyl alcohol fiber (PVAF), and glass fiber (GF) were evaluated in the anaerobic digestion of cattle manure, and the results indicated that the ACF carrier could make the reactor maintain higher biogas and methane productions than the control in the long run (Gong et al. 2011). Hence, microorganism losses can be prevented when AD microorganisms are immobilized in the above-mentioned materials or in natural crop straw (Gong et al. 2011; Li et al. 2016), thus improving the efficiency of biological treatment and the transformation of organic matter. Therefore, it is also important to fully understand the microbial compositions in the digestate and biofilms.

There have been few studies on biofilm carriers with continuous stirred tank treating dairy manure to improve biogas and methane production. The objective of this research is to analyze microbial diversity in the digestate and biofilms in the continuous stirred tank operated under optimized operating conditions using response surface methodology and the 16S rRNA clone library method. Correlations among bio-methane production, characteristics of the biofilm, and microbial compositions were studied using redundancy analysis (RDA), and these results were utilized to enhance theoretical understandings and design efficient operation strategies for anaerobic digestion in the continuous stirred tank with the immobilized carrier.

\section{EXPERIMENTAL}

\section{Materials}

Dairy manure was collected from a dairy farm near Heilongjiang Bayi Agricultural University, Heilongjiang Province, China. The $\mathrm{pH}, \mathrm{TS}, \mathrm{VS}, \mathrm{TN}$, and $\mathrm{C} / \mathrm{N}$ ratio of the manure were $7.8,17.89 \%, 16.95 \%, 1.99 \mathrm{mg} \mathrm{L}^{-1}$, and 31.9:1, respectively. The samples were kept in a refrigerator at $4{ }^{\circ} \mathrm{C}$ until the start of the experiment. The carbon fiber carrier (Nantong Senyou Carbon Fiber Co. LTD, Nangtong, Jiangsu, China) that was used in this experiment was made from adhesive fiber of the polyacrylonitrile group and asphalt.

Wang et al. (2020). "Anaerobic digestion of manure," BioResources 15(4), 7965-7979. 


\section{Methods}

Anaerobic digester design and digestion conditions

The AD device is depicted in Fig. 1. Dimensions of the AD were $31 \mathrm{~cm}$ in height, $10.4 \mathrm{~cm}$ radius, with a volume of $10 \mathrm{~L}$ and a working volume of $8 \mathrm{~L}$. Carbon fiber was used as the immobilized material, the superficial area was $1397 \mathrm{~cm}^{2}$, and it weighed $228 \mathrm{~g}$. Seven experimental reactors with the carrier and the three control tanks without the carrier were applied in this experiment. A $\mathrm{C} / \mathrm{N}$ ratio was adjusted by adding carbamide and sucrose, and the $\mathrm{pH}$ value was adjusted with $\mathrm{HCl}$ and $\mathrm{NaOH}$. The optimal digestion conditions were with a TS of $8 \%$, an HRT of $10 \mathrm{~d}$, a pH of 7.5 , a temperature of $39{ }^{\circ} \mathrm{C}$, a rotate speed of $120 \mathrm{r} \mathrm{min}{ }^{-1}$, and a $\mathrm{C} / \mathrm{N}$ ratio of 25:1 (Ma et al. 2016). The optimizing experiment was kept under the same conditions of this study. The AD reactors were fed every 5 days. Destructive sampling of the digestate and biofilm were conducted every 5 days during the two HRTs $(20 \mathrm{~d})$.

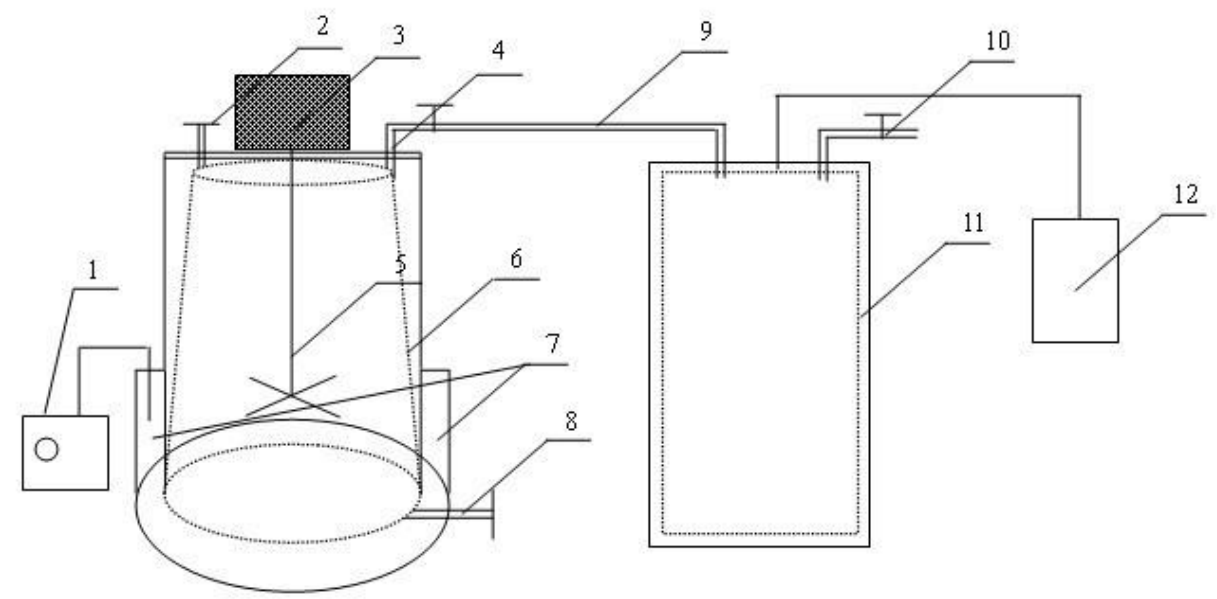

Fig. 1. Fixed bed reactor used in anaerobic digestion: (1) power supply; (2) feedstock inlet; (3) stirring motor; (4) digestate outlet port; (5) stirring paddle; (6) fixed bed frame; (7) insulation layer; (8) sampling port; (9) gas tube; (10) biogas sampling port; (11) biogas storage drum; (12) counterweight

\section{Moisture content and biomass of carrier biofilm}

The moisture content of the carrier was calculated through the ratio of moisture weight to wet weight of the carrier. For measuring biofilm biomass in the carrier, the sample was first dried to a constant weight $\left(W_{l}\right)$ at $105{ }^{\circ} \mathrm{C}$ in an oven, and then the dried sample was boiled in a $1 \mathrm{~mol} \mathrm{~L}^{-1} \mathrm{NaOH}$ solution using an electric boiler until the attachment fell off completely. The sample was then dried to a constant weight $\left(W_{2}\right)$ at $105{ }^{\circ} \mathrm{C}$ in an oven. Based on the superficial area of the carrier $(A)$, the dry weight of the biofilm $\left(M_{b} \mathrm{~g}\right.$ $\mathrm{mm}^{-2}$ ) was calculated using the following equation (1):

$$
M_{b}=\left(W_{1}-W_{2}\right) / A
$$

\section{Extracellular polymeric substances of biofilm}

The carrier sample was first rinsed using deionized water; the biofilm was peeled using an ultrasonic into suspension technique. The suspension sample was used to extract EPS through the ethylene diamine tetraacetic acid (EDTA) method (Zhang et al. 2006). Briefly, $2 \mathrm{~mL}$ of $2 \%$ EDTA solution was added into the suspension for a $3 \mathrm{~h}$ standing 
period; the mixed suspension was centrifuged for $20 \mathrm{~min}$ at $12000 \mathrm{rpm}$ to obtain the EPS solution. The EPS solution was dialyzed for $8 \mathrm{~h}$ with a dialysis membrane for which the molecular weight cut-off was $3500 \mathrm{Da}$. The solids were filtered with a cellulose membrane with a bore diameter of $0.45 \mu \mathrm{m}$. The extracellular polysaccharide was measured using the colorimetry of anthrone sulfuric acid method with glucose used as the standard. The extracellular protein was measured using the Coomassie blue colorimetric method using bovine serum albumin as the standard. Fourier transform infrared spectroscopy (FTIR) was used to compare the infrared spectrum of the biofilm during different digestion periods and to monitor the changes of molecules by analysis of their constituent bonds.

\section{Biogas and methane production}

The biogas (mainly contains methane and $\mathrm{CO}_{2}$ ) volume and methane content of 10 reactors were measured by Biogas Monitoring (QED Environmental Systems Ltd, Geotech GA2000, Coventry, UK) every 5 d. Due to the destructive sampling way method, four replicate experimental groups were conducted.

Adenosine triphosphate, chemical oxygen demand, and total organic carbon of biofilm

An ATP test kit (Shanghai Anyan Trade Co., Ltd, B079-1, Shanghai, China) was used for measuring the biofilm activity. COD and total organic carbon (TOC) were measured using a multi-purpose microcomputer COD/TOC tester (Lovibond, RD125, Dortmund, Germany).

\section{Morphological characteristics of carrier biofilm}

Morphological characteristics of the biofilm were determined using scanning electron microscopy (SEM; S4800, Hitachi, Japan).

\section{DNA extraction, PCR amplification, and purification}

The digestate and carrier membranes were sampled every $5 \mathrm{~d}$ (at $5 \mathrm{~d}, 10 \mathrm{~d}, 15 \mathrm{~d}$, and $20 \mathrm{~d}$ ) from treatment reactors. Three subsamples were composited and stored in extraction buffer at $-20{ }^{\circ} \mathrm{C}$. The method applied for the extraction of total DNA was the SDS-method (Zhou et al. 1996). A universal primer of 27F (5'-AGAGTTTGATCCTGGCTCAG-3') and 1492R (5'-GGTTACCTTGTTACGACTT-3') were applied to amplify the bacteria, and a primer of 21F (5'-TTCCGGTTGATCCYGCCGGA-3') and 915R (5'-GTGCTCCCCCGCCAATTCCT-3') were applied for the archaea.

The reaction conditions of the PCR were: pre-degenerating for $5 \mathrm{~min}$ at $94{ }^{\circ} \mathrm{C}$, degenerating for $1 \mathrm{~min}$ at $92{ }^{\circ} \mathrm{C}$, annealing for $1 \mathrm{~min}$ at $55^{\circ} \mathrm{C}$, extending $2 \mathrm{~min}$ at $72{ }^{\circ} \mathrm{C}$, and re-extending for $10 \mathrm{~min}$ at $72^{\circ} \mathrm{C}$, for a total of 25 cycles. PCR products were subjected to $1 \%$ agarose gel electrophoresis, dyed with ethidium bromide (EB), observed with Gel Doc XR, and purified using a DNA Gel Extraction Kit (BLKW Biotechnology Co., Ltd, AxyPrep, Beijing, China).

\section{Clone library construction}

The 16S rRNA T-A clone library of bacteria was constructed for the experiment. The total system volume was $10 \mu \mathrm{L}$, the purified PCR product was $3 \mu \mathrm{L}$, the PEMG-T Easy carrier was $1 \mu \mathrm{L}$, the $2 \times \mathrm{T} 4$ DNA Ligation Buffer was $5 \mu \mathrm{L}$, and the T4 DNA ligase was 1 $\mu \mathrm{L}$. The binding buffer was stored at $4{ }^{\circ} \mathrm{C}$.

The 16S rRNA T-A clone library of the archaea was also constructed with the

Wang et al. (2020). "Anaerobic digestion of manure," BioResources 15(4), 7965-7979. 
following details. The total system volume was $10 \mu \mathrm{L}$, the purified product was $4 \mu \mathrm{L}$, the PMD 19-T carrier was $1 \mu \mathrm{L}$, the solution I was $5 \mu \mathrm{L}$, and the binding buffer was stored in a water bath for $3 \mathrm{~h}$ at $16{ }^{\circ} \mathrm{C}$, and then at $4{ }^{\circ} \mathrm{C}$ overnight. The competent cell was put on ice and added to a $10 \mu \mathrm{L}$ binding buffer after it was thawed completely, and was left on the ice for another $30 \mathrm{~min}$.

The subsequent procedure included incubation at $42{ }^{\circ} \mathrm{C}$ in a water bath for $90 \mathrm{~s}$, followed immediately by an ice bath for $2 \mathrm{~min}$ to $3 \mathrm{~min}$, and injection of $400 \mu \mathrm{L} \mathrm{LB}$ culture medium into a centrifuge tube (no antibiotic). It was then cultured in the $37{ }^{\circ} \mathrm{C}$ table concentrator (150 $\mathrm{r} \mathrm{min}^{-1}, 1 \mathrm{~h}$ to $2 \mathrm{~h}$ ), centrifuged for $5 \mathrm{~min}$ at $12000 \mathrm{r} \mathrm{min}^{-1}$ under 4 ${ }^{\circ} \mathrm{C}$, and then $400 \mu \mathrm{L}$ of the liquid supernate was discarded. The cells were smeared to a culture medium which was mixed with $20 \mu \mathrm{L}$ ampicillin, $100 \mathrm{mmol} \mathrm{L}^{-1} \mathrm{IPTG}$, and $100 \mu \mathrm{L}$ and $20 \mathrm{mg} \mathrm{mL}^{-1}$ of the X-gal. The culture dishes were kept right side up for 1 hour to absorb more liquid and were then flipped and cultured for 12 hours.

\section{PCR amplification}

The PCR primers were M13-F (5'-CGCCAGGGTTTTCCCAGTCACGAC-3') and M13-R (5'-GAGCGGATAACAATTTCACACAGG-3') (BLKW Biotechnology Co., Ltd, 1519, Beijing, China). The system volume was $25 \mu \mathrm{L}$, with a $10 \times \mathrm{PCR}$ Buffer of $2.5 \mu \mathrm{L}$ $\mathrm{MagCl}_{2}(25 \mathrm{mM}) 2 \mu \mathrm{L}$, a dNTP $(10 \mathrm{mM})$ of $0.5 \mu \mathrm{L}$, a primer M13-F $0.25 \mu \mathrm{L}$, primer M13R $0.25 \mu \mathrm{L}$, a little volume of bacteria, Taq enzyme (5 unit $\mu \mathrm{L}^{-1}$ ) of $0.3 \mu \mathrm{L}$, and deionized water of $25 \mu \mathrm{L}$. Reaction conditions were at $94{ }^{\circ} \mathrm{C}$ for $5 \mathrm{~min}, 25$ cycles of $94{ }^{\circ} \mathrm{C}$ for $30 \mathrm{~s}, 62{ }^{\circ} \mathrm{C}$ for $30 \mathrm{~s}, 72{ }^{\circ} \mathrm{C}$ for $90 \mathrm{~s}$, and a final $72{ }^{\circ} \mathrm{C}$ for $10 \mathrm{~min}$. The PCR product was then added with a $1 \%$ agarose gel electrophoresis, dyed with $\mathrm{EB}$, and observed using Gel Doc XR.

\section{Enzyme cutting analysis and determination of $16 S$ rRNA clone library}

The PCR positive clone of bacteria was cut and analyzed with two kinds of restriction enzymes. MspI and HpaIII were used for bacteria and HinfI and HaeIII were used for archaea. Samples were sorted according to the macrorestriction map and the clone. The samples were then sent to BGI (The Beijing Genomics Institute, Beijing, China) and sequenced. The acquired sequence data were then analyzed for homologous comparison in the NCBI Blast. The 16S rRNA sequence was then submitted to GenBank database to obtain accession numbers. Bacterial and archaeal accession numbers of $0 \mathrm{~d}, 5 \mathrm{~d}, 10 \mathrm{~d}, 15$ d, and 20 d samples were KR107349-KR107450 and KR107451-KR107483 in digestate, and the $5 \mathrm{~d}, 10 \mathrm{~d}, 15 \mathrm{~d}$, and $20 \mathrm{~d}$ samples were KR107286-KR107348 and KR107484KR107501 on biofilm, respectively.

\section{Statistical analysis and redundancy analysis}

Spreadsheet software systems (Excel 2010 and Origin 8, Microsoft Corporation, Redmond, WA, USA) were used for analyzing and graphing. A statistics software package, SPSS Atatistics22 (SPSS Inc., IBM, Armonk, NY, USA) was used for analyzing correlation of different items. Analysis of variance (ANOVA) was used for analyzing significant difference among treatments. Correlations between the archaea structure, biofilm characteristics (volume of biofilm, ATP, EPS, moisture content, COD, and TOC) and methane production rates under different stirring time were analyzed using the Canoco 4.5 software (Ike et al. 2010).

Wang et al. (2020). "Anaerobic digestion of manure," BioResources 15(4), 7965-7979. 


\section{RESULTS AND DISCUSSION}

\section{Biogas and Methane Production}

Biogas (a) and methane (b) production during the two HRTs are shown in Fig. 2.
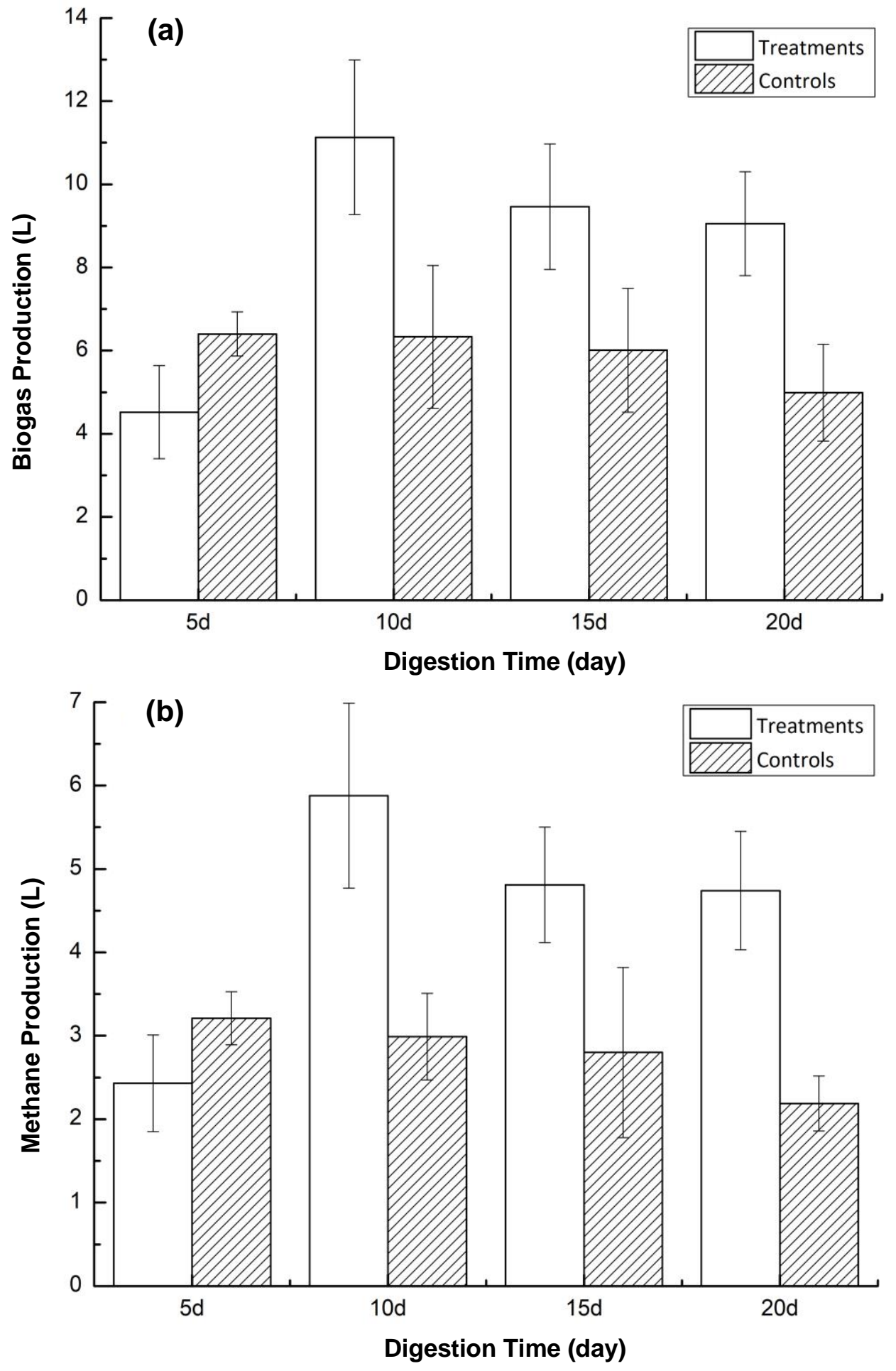

Fig. 2. Biogas (a) and methane (b) productions in control and treatment reactors 
The biogas and methane production of the treatment groups were lower than the controls in the first $5 \mathrm{~d}$, while the biogas and methane productions of $10 \mathrm{~d}, 15 \mathrm{~d}$, and $20 \mathrm{~d}$ were higher than the controls. The accumulated biogas production in the treatments with the carrier $(34.16 \mathrm{~L})$ were significantly $(\mathrm{p}<0.05)$ higher than that with the controls $(23.73$ $\mathrm{L})$. Meanwhile, the accumulated methane production of the treatments $(17.86 \mathrm{~L})$ were also significantly $(\mathrm{p}<0.05)$ higher than the controls $(11.19 \mathrm{~L})$ during the two HRTs (20 days). The addition of a carbon carrier increased the biogas and methane production by $30.53 \%$ and $37.35 \%$, respectively.

\section{Biomass, Moisture, and Extracellular Polymeric Substances of the Carrier}

Microorganisms attach to a biofilm carrier to form an EPS matrix that offers protection (Bengelsdorf et al. 2014). The biomass and moisture of the biofilm is shown in Table 1 below. The biomass of the biofilm was the highest, $1.39 \times 10^{-3} \mathrm{~g} \mathrm{~mm}^{-2}$, at $10 \mathrm{~d}$. After $10 \mathrm{~d}$, it stabilized to $0.74 \times 10^{-3} \mathrm{~g} \mathrm{~mm}^{-2}$ to $0.77 \times 10^{-3} \mathrm{~g} \mathrm{~mm}^{-2}$. The moisture of the biofilm was $18.69 \%$ at $5 \mathrm{~d}$, which decreased to $14.32 \%$ at $10 \mathrm{~d}$, and was almost the same at $15 \mathrm{~d}$. There was a trend that gradually decreased from $18.69 \%$ to $13.36 \%$. The EPS are multiple biopolymers of microbial origin in which the biofilm microorganisms are embedded. Additionally, they comprise a wide variety of proteins, glycoproteins, glycolipids, and in some cases, surprising amounts of extracellular DNA (eDNA) (Flemming et al. 2007). The amount of proteins, polysaccharides, and EPS of the biofilms in the carrier are shown in Table 1. The content of protein increased first to the highest value at $15 \mathrm{~d}$ and then decreased at $20 \mathrm{~d}$. A similar trend was observed for the polysaccharide and EPS: the samples appeared to decrease slightly at $10 \mathrm{~d}$, increased at $15 \mathrm{~d}$ and then decreased again at $20 \mathrm{~d}$. The highest values for the polysaccharide and EPS were respectively $2.404 \mathrm{mg} \mathrm{g}^{-}$ ${ }^{1}$ and $4.116 \mathrm{mg} \mathrm{g}^{-1}$. This suggested that microorganisms had high metabolism at early stages of the AD process and formed a biofilm quickly.

\section{COD, TOC, and ATP of Biofilm}

More COD means more contents of the reduced substance on the biofilm. ATP, a molecule at the center of metabolism, signals both inside and outside the living cell, and its universal importance in biology reaches well beyond its most familiar role as an energy metabolite (Rajendran et al. 2016). COD, TOC, and ATP are presented in Table 1.

Table 1. Properties of Biofilm in the Anaerobic Digestion Process

\begin{tabular}{|l|l|l|l|l|}
\hline $\begin{array}{l}\text { Digestion time } \\
(\mathrm{d})\end{array}$ & $\begin{array}{l}\text { Biomass } \\
\left(10^{-3} \mathrm{~g} \mathrm{~mm}^{-2}\right)\end{array}$ & $\begin{array}{l}\text { Moisture } \\
(\%)\end{array}$ & $\begin{array}{l}\text { Protein } \\
\left(\mathrm{mg} \mathrm{g}^{-1}\right)\end{array}$ & $\begin{array}{l}\text { Polysaccharide } \\
\left(\mathrm{mg} \mathrm{g}^{-1}\right)\end{array}$ \\
\hline 5 & $0.53 \pm 0.05$ & $18.69 \pm 2.13$ & $1.24 \pm 0.06$ & $2.20 \pm 0.23$ \\
\hline 10 & $1.39 \pm 0.16$ & $14.32 \pm 1.22$ & $1.33 \pm 0.08$ & $2.01 \pm 0.26$ \\
\hline 15 & $0.74 \pm 0.11$ & $14.30 \pm 1.19$ & $1.71 \pm 0.13$ & $2.41 \pm 0.22$ \\
\hline 20 & $0.77 \pm 0.13$ & $13.36 \pm 1.06$ & $1.58 \pm 0.11$ & $1.94 \pm 0.18$ \\
\hline $\begin{array}{l}\text { Digestion time } \\
(\mathrm{d})\end{array}$ & $\begin{array}{l}\text { EPS } \\
\left(\mathrm{mg} \mathrm{g}^{-1}\right)^{\mathrm{a}}\end{array}$ & $\begin{array}{l}\mathrm{COD} \\
\left(\mathrm{mg} \mathrm{L}^{-1}\right)^{\mathrm{b}}\end{array}$ & $\begin{array}{l}\text { TOC } \\
\left(\mathrm{mg} \mathrm{g}^{-1}\right)^{\mathrm{c}}\end{array}$ & $\begin{array}{l}\text { ATP } \\
\left(\mu \mathrm{mol} \mathrm{L}^{-1}\right)^{\mathrm{d}}\end{array}$ \\
\hline 5 & $3.44 \pm 0.31$ & $13574 \pm 263$ & $6530 \pm 161$ & $0.62 \pm 0.11$ \\
\hline 10 & $3.33 \pm 0.36$ & $13102 \pm 359$ & $6240 \pm 202$ & $0.58 \pm 0.09$ \\
\hline 15 & $4.12 \pm 0.41$ & $12367 \pm 298$ & $5950 \pm 185$ & $0.53 \pm 0.12$ \\
\hline 20 & $3.52 \pm 0.29$ & $13067 \pm 330$ & $6050 \pm 210$ & $0.56 \pm 0.08$ \\
\hline
\end{tabular}

${ }^{a}$ extracellular polymeric substance; ${ }^{b}$ chemical oxygen demand; ${ }^{c}$ total organic carbon;

d adenosine triphosphate 
Concentrations of COD in four periods ranged from $12367 \mathrm{mg} \mathrm{L}^{-1}$ to $13574 \mathrm{mg} \mathrm{L}^{-1}$, and the lower variation suggested that the AD process was stabilized, while TOC decreased and stabilized at the end of the measurement period. The variation range was also not distinct. A similar trend was observed for ATP, which stabilized at around 0.6 $\mu \mathrm{mol} \mathrm{L}{ }^{-1}$. More TOC and ATP indicated growth of the microorganisms.

\section{Morphological Characteristics of Biofilm}

The morphology of the carrier biofilm at four different periods is presented in Fig. 3. A thicker biofilm was formed when the carbon carrier that was added into the digestion system was found. Additionally, it was evident that the interspace of the carbon carrier was covered by aggregation at $20 \mathrm{~d}$. According to the increased methane production, which indicated that the biofilm formation induced by the carbon carrier promoted anaerobic digestion in the fixed bed, continuous stirred tank treating dairy manure. However, the effects of the carbon carrier on biogas digestion may be dependent on their chemical nature. Lui. et al (2017) reports polypropylene fiber used as a carrier and corn straw as a feedstock can promote more biogas production.
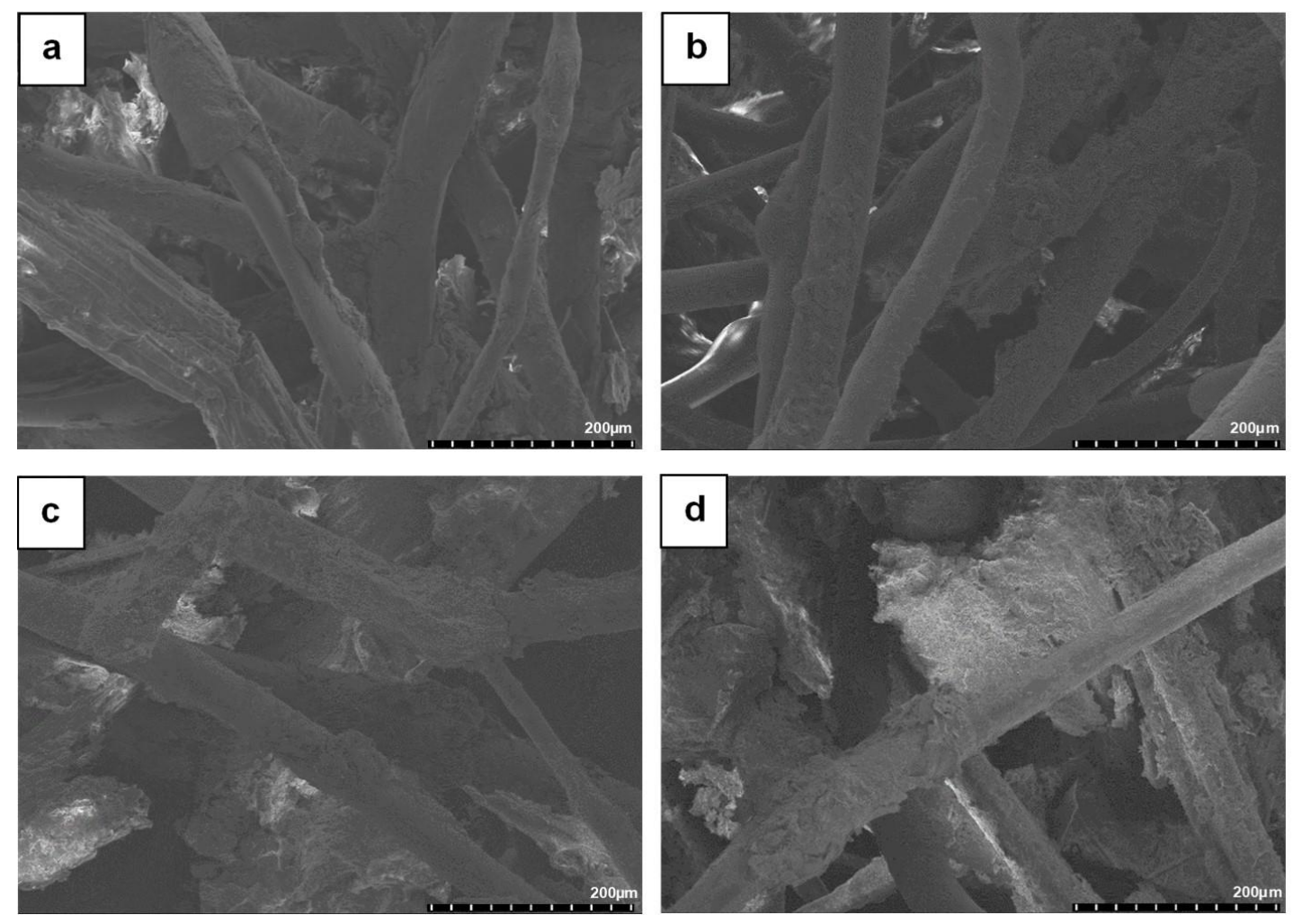

Fig. 3. SEM images for AD biofilm samples at different sampling periods: $5 d(a), 10 d(b), 15 d$ (c), and $20 \mathrm{~d}(\mathrm{~d})$; Extra High Tension (EHT) $=1.00 \mathrm{kV}$

\section{Phylogenetic Analysis for 16S rRNA of Bacteria in Biofilm and Digestate}

Microbial community compositions are determined by the digestion process, feedstocks, and reactors. The addition of carbon carrier in the CSTR digester promoted functional microorganisms (which could accelerate production of acid/ $\mathrm{H}_{2} / \mathrm{biogas}$ ), enhancing the anaerobic digestion process. Anaerobic digestion model No.1 (ADM1) includes three overall biochemical process steps: acidogenesis, acetogenesis, and 
methanogenesis (Batstone et al. 2002). Homology comparisons of bacteria in biofilm and digestate were obtained by cross-checking with the most comparable sequences in the NCBI database. Comparisons for each for the $5 \mathrm{~d}$ samples are presented in Table 2.

Table 2. Homology Comparisons of Bacteria Clones from the Biofilm and Digestate Samples

\begin{tabular}{|c|c|c|c|c|c|c|c|}
\hline \multirow{2}{*}{ OTU a } & \multirow{2}{*}{ Relative bacteria } & Homology & \multicolumn{5}{|c|}{ Biofilm/digestate clone proportion (\%) } \\
\cline { 4 - 8 } & & $(\%)$ & $0 \mathrm{~d}$ & $5 \mathrm{~d}$ & $10 \mathrm{~d}$ & $15 \mathrm{~d}$ & $20 \mathrm{~d}$ \\
\hline 1 & Pseudomonas & 99 & $0 / 20$ & $24 / 26$ & $21 / 21$ & $20 / 18$ & $18 / 17$ \\
\hline 2 & Clostridium & $95-98$ & $0 / 20$ & $21 / 19$ & $16 / 17$ & $14 / 17$ & $13 / 19$ \\
\hline 3 & Planctomycete & $97-98$ & $0 / 1$ & $1 / 2$ & $1 / 3$ & $0 / 2$ & $0 / 0$ \\
\hline 4 & Luteimonas & $98-99$ & $0 / 4$ & $0 / 4$ & $2 / 0$ & $4 / 7$ & $6 / 0$ \\
\hline 5 & Mariniphaga anaerophila & $95-99$ & $0 / 0$ & $0 / 5$ & $2 / 6$ & $8 / 3$ & $8 / 4$ \\
\hline 6 & $\begin{array}{c}\text { Syntrophobacter } \\
\text { sulfatireducens }\end{array}$ & $98-99$ & $0 / 0$ & $0 / 3$ & $8 / 7$ & $1 / 3$ & $2 / 6$ \\
\hline 7 & Bacteroidetes & $95-99$ & $0 / 7$ & $7 / 7$ & $12 / 10$ & $12 / 15$ & $15 / 16$ \\
\hline 8 & Acinetobacter & $96-97$ & $0 / 7$ & $0 / 4$ & $0 / 0$ & $0 / 6$ & $0 / 0$ \\
\hline 10 & Thauera & $98-99$ & $0 / 0$ & $0 / 0$ & $0 / 4$ & $0 / 4$ & $6 / 15$ \\
\hline 11 & $\begin{array}{c}\text { Altererythrobacter } \\
\text { atlanticus }\end{array}$ & $97-99$ & $0 / 4$ & $0 / 0$ & $3 / 4$ & $0 / 2$ & $0 / 0$ \\
\hline 12 & Uncultured bacterium & $94-99$ & $0 / 31$ & $43 / 25$ & $28 / 28$ & $31 / 22$ & $26 / 36$ \\
\hline${ }^{2}$ operational taxonomic unit
\end{tabular}

The main microorganisms in the biofilm and digestate samples included Pseudomonas (17\% to 26\%), Clostridium (13\% to 21\%), Bacteroidetes (7\% to $16 \%$ ), and Mariniphaga anaerophila (25\% to $8 \%$ ). In digestate, the relative abundance of Pseudomonas gradually decreased with the digestion process in the first HRT ( $0 \mathrm{~d}$ to $10 \mathrm{~d}$ ) and became stable in the second HRT (10 d to $20 \mathrm{~d}$ ). Pseudomonas is responsible for producing enzymes, which can effectively degrade lignocellulose and organics (Hernon et al. 2006). Methanogenesis and odor control can be improved with Pseudomonas bioaugmenting (Duran et al. 2006). The relative abundance of Clostridium was stable in the whole process. Clostridium can utilize glucose and produce ethanol, lactic acid, acetic acid, $\mathrm{CO}_{2}$, and $\mathrm{H}_{2}$, and all these intermediates are precursor substances for methane production (Xing et al. 2008). Yan et al. (2012) found microbial consortium which mainly consisted of Clostridium and could enhance the biogas production in the AD process. Clostridium can oxidize acetate in the presence of a hydrogenotrophic methanogen, Methanoculleus (Hattori 2008). The relative abundance of Bacteroidetes increased with digestion in the first HRT and was relatively stable in the second HRT. Bacteroidetes is an obligate anaerobic type of hydrolytic bacteria that can degrade polysaccharides, starches of plants, and agricultural wastes in the AD process (Wang et al. 2010; Venkiteshwaran et al. 2015). Within the biofilm, the relative abundance of Clostridium decreased with digestion time in the first HRT and became relatively stable in the second HRT. The relative abundance of Bacteroidetes and Mariniphaga anaerophila increased with the digestion process in the first HRT and was relatively stable in the second HRT. Mariniphaga anaerophila is isolated from tidal-flat sediment which utilizes D-glucose to produce succinic acid $(91.3$ $\%$ ) and acetic acid (8.7 \%) (Iino et al. 2014). The succinic acid is an intermediate of the TCA (tricarboxylic acid) cycle and one of the fermentation end-products of anaerobic metabolism. $\mathrm{CO}_{2}$ is needed by the microorganisms for succinic acid production (Bechthold 
et al. 2010). Thus, the high abundance of Mariniphaga anaerophila indicated efficient organic acid production in the AD process. The relative abundance of Pseudomonas was relatively stable in the whole anaerobic digestion.

\section{Phylogenetic Analysis for 16S rRNA of Archaea in Biofilm and Digestate}

Archaeal clones in the digestate and biofilm were cross-checked with the NCBI database and are presented in Table 3. Archaea mainly included Methanocorpusculum (25\% to $37 \%$ ), Methanosarcina (15\% to 33\%), Methanoculleus (11\% to $15 \%$ ), and Methanosaeta (13\% to $18 \%$ ). In this study, Methanoculleus was the dominant archaea in this system. Thus, it can be inferred that the occurrence of syntrophic acetate oxidization was in conjunction with the $\mathrm{H}_{2}$-consuming methanogens pathway in this system. However, this pathway is not a typical AD pathway for $\mathrm{CH}_{4}$ production (Venkiteshwaran et al. 2015). Methanoculleus are hydrogenotrophic methanogens. Methanoculleus are extreme anaerobes and mainly utilize sodium formate, $\mathrm{H}_{2}$, and $\mathrm{CO}_{2}$ to produce methane (Jiang et al. 2010). Wang et al. (2020) found high methane and biogas production treatment groups with highly abundant amounts of Methanoculleus. Archaeal compositions in the digestate were different from those in the biofilm (Table 3). In the digestate, Methanocorpusculum in the clone library was relatively stable. Nevertheless, it gradually increased within the first HRT and became relatively stable during the second HRT on the biofilm. This suggested that the Methanocorpusculum can continually accumulate on the biofilm. Methanocorpusculum is an extreme anaerobe that can utilize $\mathrm{H}_{2}, \mathrm{CO}_{2}$, and acids to produce methane, and it widely distributes in anaerobic reactors and the lake-bottom sediment (Ma et al. 2003). With digestion proceeding, Methanosarcina increased gradually within the first HRT and became relatively stable during the second HRT. However, it decreased on the biofilm, which indicated that Methanosarcina mainly occurred in the digestate but not within the biofilm. Within biofilm, Methanosaeta increased gradually during the first HRT and became stable during the second HRT. This suggested that Methanosaeta could accumulate and became stable within the biofilm. Methanosarcina and Methanosaeta are acetoclastic methanogens. Most Methanosarcina species can use $\mathrm{H}_{2}, \mathrm{CO}_{2}$, and $\mathrm{C}-1$ compounds in addition to acetate. Wang et al. (2020b) found that Methanosarcina was the optimal archaea in corn stover anaerobic digestion, and it was positively correlated with the cellulose and hemicellulose degradation rates. Methanosaeta are only known to use acetate or direct electron transport as the substrate or electron donor for methane production (Hua 2010; Venkiteshwaran et al. 2015). Methanosaeta are abundant in deep sediment and endosymbiont, which exist in infusorian (Ike et al. 2010). Methanosaeta was the dominant methanogen in the cattle manure fermentation (Gao et al. 2017). The activity of Methanosaeta increased from $2.0 \%$ to $10.1 \%$, which significantly enhanced the ability of the community to capture acetic acid and reduce $\mathrm{CO}_{2}$ to methane with biological pretreatment (Zhao et al. 2019). Methanobacterium, a type of hydrogenotrophic methanogen, was only found at the second HRT. Methanoculleus are extreme anaerobes and mainly utilize sodium formate, $\mathrm{H}_{2}$, and $\mathrm{CO}_{2}$ to produce methane (Jiang et al. 2010). Wang et al. (2020a) found that high methane and biogas production treatment groups had a high abundance of Methanoculleus. Bertin et al. also found that Methanobacterium obtained energy from the reduction process of $\mathrm{CO}_{2}$ being restored to produce methane and $\mathrm{H}_{2}$ (Bertin et al. 2004; Xing et al. 2008). Methanobacterium formicicum was also the dominant archaea in anaerobic digestion olive mill wastewaters using granularly activated carbon as packed-bed biofilm. Thus, these findings suggest that Methanobacterium 
adhered to carbon carriers, which increased its methane production. There were also some other bacterial communities in the digestate and biofilm samples, but the relative abundances of these were more variable. The dominant archaea in the digestate and biofilm were similar, and much of the amount tended to decrease over time. This suggested that biofilm efficiently immobilized bacterial communities to enhance biogas production.

Table 3. Homology Comparisons of Archaeal Clones and Their Percentage to the Total Clones in the Biofilm and Digestate Samples

\begin{tabular}{|c|c|c|c|c|c|c|c|}
\hline \multirow{2}{*}{ OTU a } & \multirow{2}{*}{ Relative archaea } & \multirow{2}{*}{$\begin{array}{l}\text { Homology } \\
(\%)\end{array}$} & \multicolumn{5}{|c|}{ Biofilm/digestate clone number } \\
\hline & & & $0 \mathrm{~d}$ & $5 d$ & $10 \mathrm{~d}$ & $15 \mathrm{~d}$ & $20 d$ \\
\hline 1 & Methanocorpusculum & 99 & $0 / 37$ & $25 / 27$ & $29 / 31$ & $32 / 30$ & $31 / 27$ \\
\hline 2 & Methanosarcina & $90-100$ & $0 / 27$ & $27 / 24$ & $24 / 33$ & $15 / 29$ & $0 / 28$ \\
\hline 3 & Methanoculleus & $95-97$ & $0 / 0$ & $0 / 12$ & $15 / 0$ & $0 / 11$ & $0 / 0$ \\
\hline 4 & Methanosaeta & $95-98$ & $0 / 0$ & $0 / 14$ & $18 / 0$ & $15 / 17$ & $13 / 0$ \\
\hline 5 & Nitrosocaldus & $97-98$ & $0 / 0$ & $0 / 0$ & $0 / 9$ & $0 / 0$ & $7 / 0$ \\
\hline 6 & Methanobacterium & $98-99$ & $0 / 0$ & $0 / 0$ & $0 / 0$ & $15 / 0$ & $8 / 8$ \\
\hline 7 & Methanoplanus & $95-99$ & $0 / 0$ & $9 / 0$ & $0 / 0$ & $0 / 0$ & $0 / 0$ \\
\hline 8 & $\begin{array}{l}\text { Uncultured archaeon } \\
\text { clone }\end{array}$ & $94-99$ & $0 / 36$ & $40 / 23$ & $14 / 27$ & $23 / 13$ & $40 / 37$ \\
\hline
\end{tabular}

\section{Redundancy Analysis of Bacteria and Archaea on Biofilm}

The RDA analysis indicated significant correlations between the biofilm properties, methane production rate, and variations of bacteria and archaea (Fig. 4). The methane production rate was highly correlated with Pseudomonas (OTU1), Clostridium (OTU2), and Altererythrobacter atlanticus (OTU11). The samples from $5 \mathrm{~d}$ and $10 \mathrm{~d}$ were separated from samples of $15 \mathrm{~d}$ and $20 \mathrm{~d}$. This indicated that bacterial compositions in the first HRT was significantly different from those in the second HRT.

Archaeal samples of $5 \mathrm{~d}$ and $10 \mathrm{~d}$ were significantly different, while samples of 15 $\mathrm{d}$ and $20 \mathrm{~d}$ were similar. This suggested that archaeal compositions were not stable in the first HRT and that they were relatively stable during the second HRT. There was a significant correlation between the methane production rate and Methanosarcina (OTU2), Methanculleus (OTU3), Methanosaeta (OTU4), and Methanoplanus (OTU7), suggesting their important roles in methane production. There was a significant correlation between the methane production rate and biofilm characteristics (specifically the moisture, COD, and amount of biofilm). The variations of archaeal communities after $10 \mathrm{~d}$ or during the second HRT were relatively small, suggesting that the biofilm of the archaea community was stabilized after the second HRT.

The relative abundances of the bacterial taxa (Pseudomonas, Clostridium, Altererythrobacter atlanticus), archaea community (Methanosarcina, Methanculleus, Methanosaeta, and Methanoplanus), and biofilm characteristics (COD and EPS) were highly correlated with the methane production. The biogas production rates in the performed batch experiments were strongly correlated to the overall biofilm development, as reported in the literature (Langer et al. 2014). The methane production rate was related to the quantity of COD removed, which reflected the balance between the flows of the organic carbon to catabolism and anabolism in the methanogenic ecosystems (Michaud et al. 2005). The consolidate EPS matrix may be led by high detachment forces which could increase the biofilm thickness (Stoodley et al. 2002). 


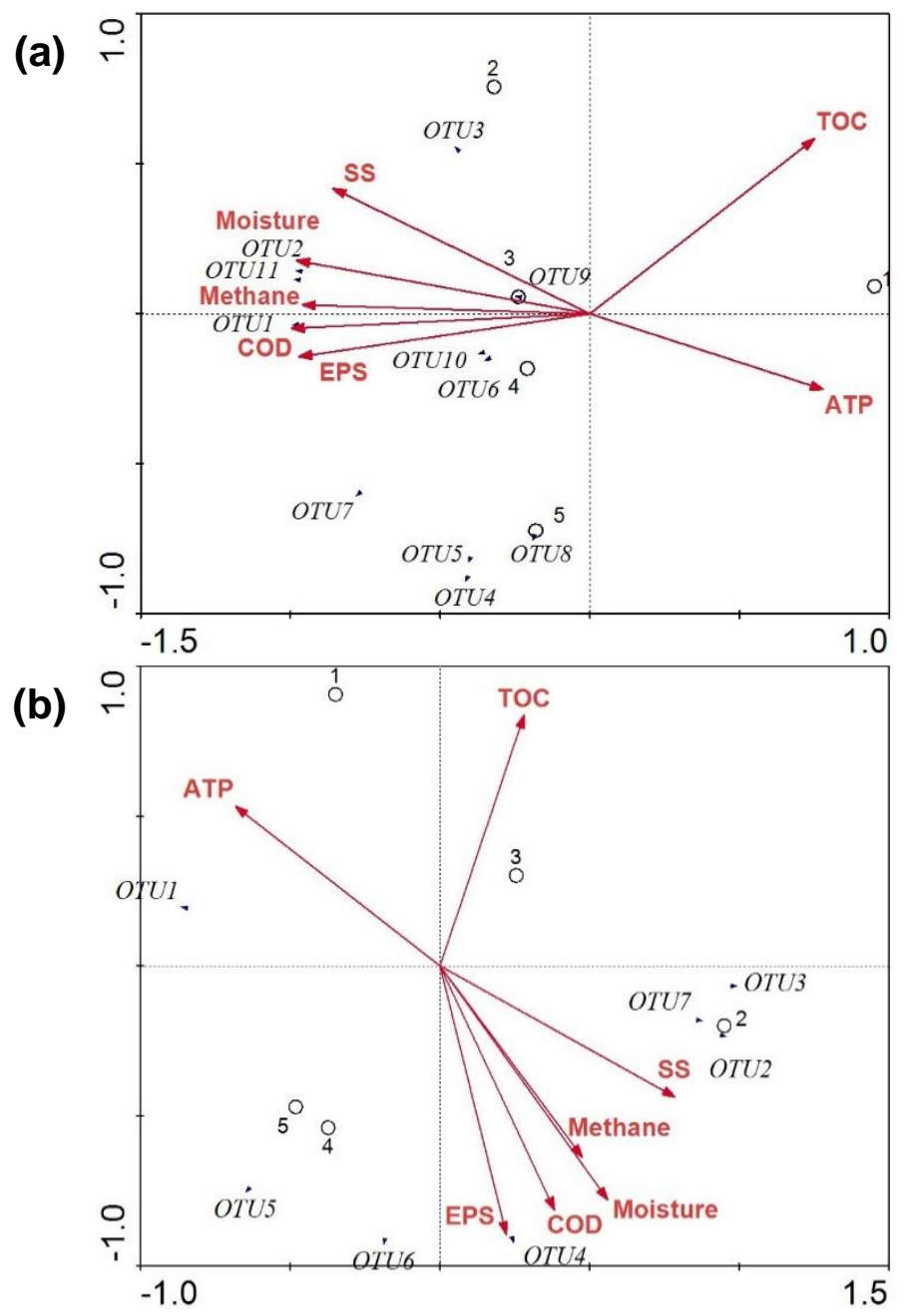

Fig. 4. (a) RDA of bacterial OTUs, biofilm properties, and methane production rate. Circles with number 1, 2, 3, 4 and 5 represents samples from $0 \mathrm{~d}, 5 \mathrm{~d}, 10 \mathrm{~d}, 15 \mathrm{~d}$ and $20 \mathrm{~d}$. (b) The RDA of archaea OTUs, characteristics of the biofilm and methane production rate. Different samples are shown with circle (samples of fermentation time 1, 2, 3, 4 and 5 to $0 \mathrm{~d}, 5 \mathrm{~d}, 10 \mathrm{~d}, 15 \mathrm{~d}$ and $20 \mathrm{~d}$ ). The biofilm bacteria are shown with short arrows. The characteristics of the biofilm and methane production rate are shown with long arrows.).

\section{CONCLUSIONS}

1. The addition of carbon fiber carrier significantly increased the biogas production in this anaerobic digestion (AD) process

2. A stable biofilm formed at the second hydraulic retention time (HRT), which meant that biofilm would need more time to form a stable structure.

3. The chemical oxygen demand (COD) and extracellular polymeric substances (EPS) had a significant correlation with the dominant bacterial taxa (Pseudomonas, Clostridium, and Bacteroidetes), archaea (Methanocorpusculum, Methanosarcina, Methanoculleus, and Methanosaeta) and methane production. 


\section{ACKNOWLEDGMENTS}

This research was funded by the National Key Research Program and development plan (2019YFD1100304-03); Key Project of Heilongjiang Natural Science Foundation (ZD2018005); University of Missouri Extension; The local science and technology development program supported by the central government (ZY16A06-02); The Program of Research and Development Plan of Heilongjiang Agricultural Company (HKKY190404); the Support Program of Scientific Research Team and Platform of HBAU (TDJH201809), and Program of Science and Technology Innovation Team in Heilongjiang Province (2012TD006).

\section{REFERENCES CITED}

Abbasi, T. and Abbasi, S. A. (2010). "Biomass energy and the environmental impacts associated with its production and utilization," Renewable Sustainable Energy Rev. 14(3), 919-937. DOI: org/10.1016/j.rser.2009.11.006

Batstone, D. J., Keller, J., Angelidaki, I., Kalyuzhnyi, S. V., Pavlostathis, S. G., Rozzi, A., Sanders, W. T. M., Siegrist, H., and Vavilin, V. A. (2002). "The IWA anaerobic digestion model No. 1 (ADM1)," Water Sci. Technol. 45(10), 65-73. DOI: 10.2166/wst.2002.0292

Bechthold, I., Bretz, K., Kabasci, S., and Kopitzky, R. (2010). "Succinic acid: A new platform chemical for biobased polymers from renewable resources," Chem. Eng. Technol. 31(5), 647-654. DOI: 10.1002/ceat.200800063

Bengelsdorf, F. R., Langer, S., and Kern, M. (2014). "Additional biofilms improve the anaerobic digestion of food leftovers," in: $2^{\text {nd }}$ International Conference on Biogas Microbial Icbm, Uppsala, Sweden.

Bertin, L., Colao, M. C., Ruzzi, M., and Fava, F. (2004). "Performances and microbial features of a granular activated carbon packed-bed biofilm reactor capable of an efficient anaerobic digestion of olive mill wastewaters," FEMS Microbiol. Ecol. 48(3), 413-423. DOI: 10.1016/j.femsec.2004.03.009

Duran, M., Tepe, N., Yurtsever, D., Punzi, V. L., Bruno, C., and Mehta, R. J. (2006). "Bioaugmenting anaerobic digestion of biosolids with selected strains of Bacillus, Pseudomonas, and Actinomycetes species for increased methanogenesis and odor control," Appl. Microbiol. Biotechnol. 73(4), 960-966. DOI: 10.1007/s00253-0060548-6

Flemming, H. C., Neu, T. R., and Wozniak, D. J. (2007). "The EPS matrix: The 'house of biofilm cells'," J. Bacteriol. 189(22), 7945-7950. DOI: 10.1128/JB.00858-07

Gao, Y. M., Yang, A. Y., Bao, J., Ma, R. X., Yan, L., Wang, Y. J., and Wang, W. D. (2017). "Bioreactor performance and microbial community dynamics in a productionscale biogas plant in Northeast of China," Int. J. Agric. Biol. Eng. 10(1), 191-201. DOI: $10.3965 /$ j.ijabe.20171001.2025

Gong, W. J., Liang, H., Li, W. Z., and Wang, Z. Z. (2011). "Selection and evaluation of biofilm carrier in anaerobic digestion treatment of cattle manure," Energy 36(5), 3572-3578. DOI: 10.1016/j.energy.2011.03.068

Hattori, S. (2008). "Syntrophic acetate-oxidizing microbes in methanogenic environments," Microbes Environments 23(2), 118-127. DOI: 10.1264/jsme2.23.118 
Hernon, F., Forbes, C., and Colleran, E. (2006). "Identification of mesophilic and thermophilic fermentative species in anaerobic granular sludge," Water Sci. Technol. 54(2), 19-24. DOI: 10.2166/wst.2006.481

Hua, W. Y. (2010). The Method Study of the Application of 454 Sequencing on Microbial Community Analysis, Master's Thesis, Shanghai Jiao Tong University, School of Life Sciences and Biotechnology, Shanghai, China.

Iino, T., Mori, K., and Itoh, T. (2014). "Description of Mariniphaga anaerophila gen. nov. sp. nov. a facultatively aerobic marine bacterium isolated from tidal flat sediment, reclassification of the draconibacteriaceae as a later heterotypic synonym of the prolixibacteraceae and description of the family Marinifilaceae fam. nov., "Int. J. Syst. Evol. Microbiol. 64(11), 3660-3667. DOI: 10.1099/ijs.0.066274-0

Ike, M., Inoue, D., and Miyano, T. (2010). "Microbial population dynamics during startup of a full-scale anaerobic digester treating industrial food waste in Kyoto ecoenergy project," Bioresource Technol. 101(11), 3952-3957.

DOI: 10.1016/j.biortech.2010.01.028

Jiang, N., Wang, Y., and Dong, X. (2010). "Methanol as the primary methanogenic and acetogenic precursor in the cold zoige wetland at Tibetan plateau," Microb. Ecol. 60(1), 206-213. DOI: 10.2307/40802286

Langer, S., Schropp, D., and Bengelsdorf, F. R. (2014). "Dynamics of biofilm formation during anaerobic digestion of organic waste," Anaerobe 29, 44-51. DOI:

10.1016/j.anaerobe.2013.11.013

Langerak, E. P. A. V., Gonzalez-Gil, G., and Aelst, A. V. (1998). "Effects of high calcium concentrations on the development of methanogenic sludge in upflow anaerobic sludge bed (UASB) reactors," Water Res. 32(4), 1255-1263. DOI: 10.1016/S0043-1354(97)00335-7

Li, R. P., Li, X. J., and Chen, S. (2007). "Performance evaluation of anaerobic digestion of dairy manure in plug flow reactor and continuous stirred tank reactor," Trans. Chin. Soc. Agric. Eng. 23(9), 186-190.

Li, X., Liu, Y. H., and Zhang, X. (2016). "Evaluation biogas production performance and dynamics of the microbial community in different straw," J. Microbiol. Biotechnol. 27(3), 524-534. DOI: 10.4014/jmb.1608.08062

Liu, Y., Zhu, Y., and Jia, H. (2017). "Effects of different biofilm carriers on biogas production during anaerobic digestion of corn straw," Bioresource Technol. 244(1), 445-451. DOI: 10.1016/j.biortech.2017.07.171

Ma, R. X., Hong, Y. H., Ai, S. Q., Deng, B., Jia, J., Yan, L., and Wang, W. D. (2016). "Optimization of fermentation conditions of mixing type fixed bed reactor using cow manure as the feedstock," J. Heilongjiang Bayi Agric. Univ. 28(3),105-112.

Ma, Y., Homstrm, C., and Webb, J. (2003). "Application of denaturing gradient gel electrophoresis (DGGE) in microbial ecology," Acta Ecologica Sinica 23(8), 15611569. DOI: $10.5772 / 38177$

Michaud, S., Bernet, N., and Buffière, P. (2005). "Use of the methane yield to indicate the metabolic behaviour of methanogenic biofilms," Process Biochem. 40(8), 27512755. DOI: 10.1016/j.procbio.2004.12.017

Rajendran, M., Dane, E., and Conley, J. (2016). "Imaging adenosine triphosphate (ATP)," Biol. Pharm. Bull. 231(1), 73-84. DOI: 10.1086/689592

Schauer-Gimenez, A. E., Zitomer, D. H., and Maki, J. S. (2010). "Bioaugmentation for improved recovery of anaerobic digesters after toxicant exposure," Water Res. 
44(12), 3555-3564. DOI: 10.1016/j.watres.2010.03.037

Stoodley, P., Cargo, R., and Rupp, C. J. (2002). "Biofilm material properties as related to shear-induced deformation and detachment phenomena," J. Ind. Microbiol.

Biotechnol. 29(6), 361-367. DOI: 10.1038/sj.jim.7000282

Usack, J. G., Spirito, C. M., and Angenent, L. T. (2012). "Continuously-stirred anaerobic digester to convert organic wastes into biogas: system setup and basic operation," $J$. Visualized Exp. 65, e3978. DOI: 10.3791/3978

Venkiteshwaran, K., Bocher, B., Maki, J., and Zitomer, D. (2015). "Relating anaerobic digestion microbial community and process function: Supplementary issue: Water microbiology," Microbiol. Insights 8(2), 37-44. DOI: 10.4137/MBI.S33593

Wang, H., Tolvanen, K., Lehtomäki, A., Puhakka, A., and Rintala, J. (2010). "Microbial community structure in anaerobic co-digestion of grass silage and cow manure in a laboratory continuously stirred tank reactor," Biodegrad. 21(1), 135-146. DOI: $10.1007 / \mathrm{s} 10532-009-9288-5$

Wang, H. P., Lim, T. T., Duong, C., Zhang, W., Xu, C. F., Yan, L., Mei, Z. L., and Wang, W. D. (2020a). "Long-term mesophilic anaerobic co-digestion of swine manure with corn stover and microbial community analysis," Microorganisms 8, 188. DOI: 10.3390/microorganisms8020188

Wang, H. P., Li, J. W., Zhang, Y. Q., Xu, C. F., Zhang, K. Q., Li, J. J., Yan, L., Gu, J. D., Wei, D., and Wang, W. D. (2020b). "Establishing practical strategies to run high loading corn stover anaerobic digestion: Methane production performance and microbial responses," Bioresource Technol. 310, 123364. DOI: 10.1016/j.biortech.2020.123364

Xing, W., Zuo, J. E., Lin, J., and Li, J. (2008). "Microbial community in granules from an EGSB reactor operated at $20^{\circ} \mathrm{C}$," Environ. Sci. 29(9), 2558-2563.

Yan, L., Gao, Y. M., Wang, Y. J., Liu, Q., Sun, Z. Y., Fu, B. R., Wen, X., Cui, Z. J., and Wang, W. D. (2012). "Diversity of a mesophilic lignocellulolytic microbial consortium which is useful for enhancement of biogas production," Bioresource Technol. 111, 49-54. DOI: 10.1016/j.biortech.2012.01.173

Zhang, G. M., Zhang, P. Y., Wang, B., and Liu, H. (2006). "Ultrasonic frequency effects on the removal of Microcystis aeruginosa," Ultrason. Sonochem. 13(5), 446-450. DOI: 10.1016/j.ultsonch.2005.09.012

Zhao, Y. Q., Xu, C. F., Ai, S. Q., Wang, H. P., Gao, Y. M., Yan, L., Mei, Z. L., and Wang, W. D. (2019). "Biological pretreatment enhances the activity of functional microorganisms and the ability of methanogenesis during anaerobic digestion," Bioresource Technol. 290, 121660. DOI: org/10.1016/j.biortech.2019.121660

Zhou, J., Bruns, M. A., and Tiedje, J. M. (1996). "DNA recovery from soils of diverse composition," Appl. Environ. Microbiol. 62(2), 316-322. DOI:10.1002/bit.260490302

Article submitted: June 1, 2020; Peer review completed: August 3, 2020; Revised version received and accepted: August 31, 2020; Published: September 3, 2020.

DOI: 10.15376/biores.15.4.7965-7979 